\title{
ENVIRONMENTAL ASSESSMENT OF LIVESTOCK FARMS IN RUSSIA
}

Natalia KOZLOVA, Institute for Engineering and Environmental Problems in Agricultural Production (IEEP), Department of Environmental Safety Farming', Federal State Budget Scientific Institution, 196625 Filtrovskoje shosse, 3, Saint Petersburg, p.o.Tiarlevo, Russian Federation, natalia.kozlova@sznii.ru (corresponding author)

Aleksandr BRIUKHANOV, Institute for Engineering and Environmental Problems in Agricultural Production (IEEP), Department of Environmental Safety Farming, Federal State Budget Scientific Institution, 196625 Filtrovskoje shosse, 3, Saint Petersburg, p.o.Tiarlevo, Russian Federation, sznii@yandex.ru

Eduard VASILEV, Institute for Engineering and Environmental Problems in Agricultural Production (IEEP), Department of Environmental Safety Farming, Federal State Budget Scientific Institution, 196625 Filtrovskoje shosse, 3, Saint Petersburg, p.o.Tiarlevo, Russian Federation, sznii6@yandex.ru

Ekaterina SHALAVINA, Institute for Engineering and Environmental Problems in Agricultural Production (IEEP), Department of Environmental Safety Farming, Federal State Budget Scientific Institution, 196625 Filtrovskoje shosse, 3, Saint Petersburg, p.o.Tiarlevo, Russian Federation, shalavinaev@ mail.ru

The paper focuses on quantitative assessment of nitrogen flows in a livestock farm under transition to best available techniques BAT system in Russia. Comparative analysis of quantitative estimates of ammonia emissions from housing for dairy cows, fattening pigs, farrowing sows and laying hens was conducted using available literature data and information obtained through a survey of pilot livestock farms in Leningrad Region. Ammonia emission data for existing Russian enterprises were found in the range of BREF emission levels associated with BAT.

The nitrogen farm-gate balance was calculated for the farm with 810 dairy cows, 2600 ha of agricultural land and milk yield of 22 $\mathrm{kg} / \mathrm{day}$. The nitrogen surplus was $48.3 \mathrm{~kg} / \mathrm{ha}$, which was below the limit values and indicated the possibility to increase the application amount of nitrogen fertilisers, however, nitrogen use efficiency of 0.21 was significantly below the European average. The viability of manure storage and spreading techniques recommended by European BREF, namely compost heaps covering and immediate incorporation of organic fertilisers after spreading, was estimated for this farm. The calculated values of total nitrogen losses are reduced by $20 \%$; the saving of mineral fertilizers owing to higher nitrogen content in applied organic fertilisers can be $18 \mathrm{t} /$ year. For the rough assessment of technologies on the initial stage of Russian reference books creation it is practicable to use the data from EU BREF on intensive rearing of pigs and poultry. When farms are assessed on the stage of integrated permits issue, it is feasible to use the measured air concentrations of hazardous substances along with the estimation of the whole-farm environmental impact by nitrogen use efficiency. For such estimates to be applied in Russia, the data needs to be collected and systematised for different categories of farms and for different climatic regions.

Keywords: ammonia, environmental impact, livestock farm, farm-gate balance, nitrogen use efficiency

\section{INTRODUCTION}

Currently the reforms of environmental legislation are in progress in Russia. They envisage, among others, the transition to the system of best available techniques (BAT) in all industries, including intensive livestock production. Creation of relevant Russian BAT reference books also continues. The latest version of Best Available Techniques Reference Document (BREF) on intensive rearing of pigs and poultry is used as an analogue (Santonja et al., 2017).

One of the key issues in this process is to find and agree upon the assessment criteria of environmental impact of farm facilities. The importance of such an assessment of livestock enterprises and applied technologies is highlighted by the current practical needs of the on-going reforms. This assessment is especially required to identify separate technological processes as BAT, to estimate the effectiveness of undertaken environmental measures at the stage of issuing the integrated environmental permits, and to calculate the required investments for BAT introduction in animal husbandry at farm, region and country level.

Requirements to livestock facilities, specified in the valid Russian regulatory documents, are much the same as those of European standards. Fundamentally new in the transition of Russia to BAT system is the requirement to quantify the level of negative impact of technologies on the environment. But it is not easy to establish such normative in this context because of the diffuse nature of environmental load from agricultural enterprises.

Copyright (C) 2017 The Authors. Published by Aleksandras Stulginskis University. This is an open-access article distributed under the terms of the Creative Commons Attribution License (CC-BY 4.0), which permits unrestricted use, distribution, and reproduction in any medium, provided the original author and source are credited. 
Analysis of agricultural production processes as the source of environmental impact showed that major pollution is associated with manure handling systems, with the basic pollutants being nitrogen and phosphorus compounds. European regulatory documents consider ammonia emission into the atmosphere as one of the key indicators of environmental effect of livestock installations (Santonja et al., 2017). Presently in Russia the values of maximum concentrations of harmful gases at the border of the sanitary protection zone are rated and the concentration rates of ammonia, carbon dioxide, hydrogen sulfide and dust content in the air of livestock houses are set. The lack of special national studies focused on harmful emissions from livestock facilities should be noted. Current methodological guidelines for calculation of pollutant emissions from livestock installations (SRI Atmosphere, 1999) require updating with due account for modern technologies.

In this regard the highly topical issue today is to identify approaches to environmental assessment of intensive livestock farming and to assess the feasibility of applying the existing and promising European solutions In Russian conditions. This article deals with the problem of quantitative assessment of nitrogen flows in a livestock farm under transition to BAT system in Russia.

\section{METHODS}

Different level models have been developed (Sutton et al., 2011) to study nitrogen flows in livestock production. In this research, the FarmAC model provided by Aarhus University, Faculty of Science and Technology, Department of Agroecology, was used for general assessment of nitrogen flows to the atmosphere from the animal houses, manure storages and field application on the farm (dairy + cropping). The model has great potential, especially when reliable source data are available. In this research, the simulation results were used for approximate estimation of nitrogen flows.

Comparative analysis of quantitative estimates of ammonia emissions from livestock housing was conducted using available literature data and information obtained through a survey of pilot livestock farms in Leningrad Region. European BREF on intensive rearing of pigs and poultry (Santonja et al., 2017) as well as the documents under the Convention on Long-Range Transboundary Air Pollution (CLRTAP) were considered: EMEP/EEA air pollutant emission inventory guidebook (EMEP/EEA, 2015) and the Guidance document for Preventing and Abating Ammonia Emissions from Agricultural Sources (Ammonia Guidance document) (Bittman et al. 2014) prepared by the Task Force on Reactive Nitrogen within CLRTAP.

The nitrogen flows on a livestock farm were analysed using farm-gate balance and nitrogen balance with the use of the Eurostat and OECD Nutrients Budgets Methodology (Eurostat. 2013).

\section{AMMONIA EMISSION IN ENVIRONMENTAL ASSESSMENT}

The principal sources of nitrogen compounds emissions in the atmosphere from a livestock enterprise are animal houses, manure storages and manure application techniques. Approximate contribution of each of these sources in air pollution is shown by the example of a cattle farm with 800 cows with the productivity of $7000 \mathrm{~kg}$ of milk per year and 760 ha of arable land in Figure 1. The diagram is based on the simulation results of nitrogen flows using the FarmAC model. The source calculation data concerning animal productivity and applied technologies are representative for Leningrad Region. Three combinations of technologies were considered: Option 1 - tied animal housing, not covered manure storage, broadcast spreading of manure; Option 2 - loose animal housing, covered manure storage and broadcast spreading of manure; Option 3 - loose animal housing, covered manure storage and manure injecting.

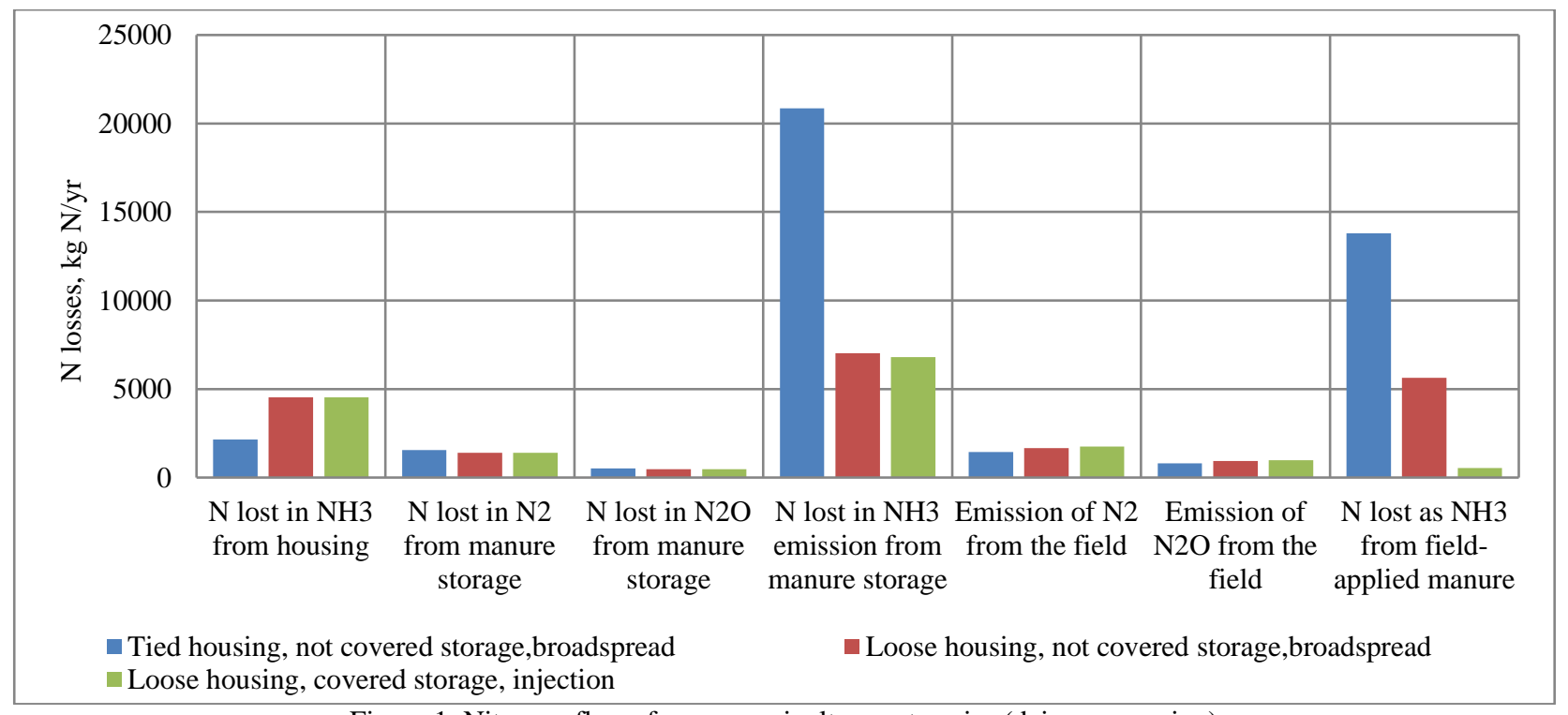

Figure 1. Nitrogen flows from an agriculture enterprise (dairy + cropping) 
Simulation results show that the main nitrogen losses into the atmosphere occur with ammonia $\mathrm{NH}_{3} . \mathrm{N}_{2}$ and $\mathrm{N}_{2} \mathrm{O}$ flows in the farm environmental assessment may be neglected. Figure 1 also shows that when justifying emission abatement measures the production chain needs to be considered as a whole to avoid pollution swapping. For example, at a lower ammonia emission level from the livestock house, the loss from the manure storage increases. Similar conclusions are found in (Santonja et al., 2017).

\section{POSSIBLE RATING OF AMMONIA EMISSIONS}

All normative ecology-related European documents are based on the synthesis of numerous resent research results in different countries for various categories of animals. The most investigated are ammonia emissions from livestock houses, the range of which depends on many factors - the type and productivity of animals, feeding and housing practices, manure removal systems, operation modes of ventilation systems, and management level. The main problem to make use of a lot of experimental data is the difficulty to compare and summarise them since different research methods, especially for buildings with natural ventilation, are applied (Sanz, et al., 2013). In the future, the quality of emission estimates should improve owing to standardisation of techniques and development of the Test Protocol for Livestock Housing and Management Systems within VERA (Verification of Environmental Technologies for Agricultural Production) project (VERA. 2011).

Table 1 shows the values of ammonia emissions from the livestock housing for the following categories of animals: dairy cows, fattening pigs, farrowing sows and laying hens (cage system). To facilitate comparison of the obtained data, the ammonia emission values from different sources were recalculated and presented in "kg of $\mathrm{NH}_{3}$ per animal place per year".

Column A shows ammonia emission factors from livestock housing (Tier 2 method) (EMEP/EEA, 2015) used in the annual reports to EMEP of the parties to the Convention. The main source of ammonia emissions on a national scale is the livestock manure management system (about $80 \%$ of total ammonia losses from all other sources). In current reporting the Russian Federation shows specific ammonia emissions per head per year without taking into account the technology in place (Tier 1 method) (Morozova et al.,2014).

Column B shows the data on ammonia emissions by the reference (the most common) housing system according to the Ammonia Guidance document.

Column C shows the BREF data (Santonja et al., 2017). Emission levels associated with the BAT (BAT-AELs) are close to our understanding of the "normative". They are set for the level of ammonia emissions from housing for different categories of pigs and poultry. It is assumed that these levels of emissions correspond to the livestock house, where all elements are identified as BAT.

Table 1. Rough estimates of BAT-AELs for animal houses in the North-West Russia $\mathrm{kg} \mathrm{NH}_{3} /$ animal place/year

\begin{tabular}{|c|c|c|c|c|c|c|c|}
\hline \multirow{4}{*}{ Animal category } & \multicolumn{3}{|c|}{$\begin{array}{c}\text { European estimates, } \mathrm{kgNH}_{3} / \mathrm{animal} \\
\text { place/year }\end{array}$} & \multicolumn{2}{|c|}{$\begin{array}{c}\text { Russian estimates, } \\
\mathrm{kgNH}_{3} / \text { animal place/year }\end{array}$} & \multicolumn{2}{|c|}{ Notes } \\
\hline & EMEP/EEA & Ammonia & conoon & Current & $\begin{array}{l}\text { Calculation } \\
\text { according to }\end{array}$ & \multirow{2}{*}{\multicolumn{2}{|c|}{$\begin{array}{l}\text { Legal Russian requirements to } \\
\text { indoor air quality }\end{array}$}} \\
\hline & guidebook & & & $\begin{array}{l}\text { the North- } \\
\text { West Russia }\end{array}$ & $\begin{array}{l}\text { to indoor air } \\
\text { quality }\end{array}$ & & \\
\hline & $\begin{array}{l}\text { Emission } \\
\text { factor }\end{array}$ & $\begin{array}{l}\text { Emissions } \\
\text { for } \\
\text { reference } \\
\text { livestock } \\
\text { housing }\end{array}$ & $\begin{array}{l}\text { BAT- } \\
\text { AELs }\end{array}$ & $\begin{array}{l}\text { Estimated } \\
\text { emissions } \\
\text { from animal } \\
\text { houses }\end{array}$ & $\begin{array}{l}\text { Estimated } \\
\text { (maximum } \\
\text { possible) } \\
\text { ammonia } \\
\text { emission }\end{array}$ & $\begin{array}{l}\text { Ventilation rate } \\
\text { Winter/summer } \\
\mathrm{m}^{3} / \mathrm{h} \text { per one } \\
\mathrm{kg} \text { of live } \\
\text { weight }\end{array}$ & $\begin{array}{c}\text { Maximum } \\
\text { permissible } \\
\mathrm{NH}_{3} \\
\text { concentration } \\
\mathrm{mg} / \mathrm{m}^{3}\end{array}$ \\
\hline & $\mathrm{A}$ & $\mathrm{B}$ & $\mathrm{C}$ & $\mathrm{D}$ & $\mathrm{E}$ & $\mathrm{F}$ & $\mathrm{G}$ \\
\hline Dairy cows & 17.6 & 12 & - & $5.3-11.6^{*}$ & 13.1 & 0.15 & 20 \\
\hline Fattening pigs & 2.87 & 3 & $\begin{array}{c}0.1-2.6 \\
\max 5.65\end{array}$ & $1.9-3$ & 4.68 & $0.3 / 0.6$ & 20 \\
\hline Farrowing sows & 6.45 & 8.3 & $\begin{array}{l}0.4-5.6 \\
\max 7.5\end{array}$ & $1.7-2.74$ & 15.6 & $0.3 / 0.6$ & 20 \\
\hline $\begin{array}{l}\text { Laying hens, } \\
\text { cage system }\end{array}$ & 0.268 & $0.1-0.2$ & $0.02-0.08$ & 0.03 & 0.27 & $0.7 / 6$ & 15 \\
\hline
\end{tabular}

*Estimates of emissions from cattle houses result from our previous investigations in the cow barns in Leningrad Region (Kozlova and Maximov, 2010).

Column D shows the approximate numerical values of ammonia emissions from pig and poultry housing, which result from the questionnaire survey of pilot farms in Leningrad Region, conducted by IEEP in the study to substantiate the methodology for compiling Russian BAT reference books (Briukhanov et al., 2016). Table 1 presents the data from the legal documents under the title "Permit for emission of harmful (polluting) substances in atmospheric air (except for radioactive substances)". These documents are developed by specialised organisations for large livestock enterprises in Russia using the standard methods (SRI Atmosphere, 1999). Emissions from livestock houses are mainly calculated; for the housing with mechanical ventilation, one-time instrumental measurements are made. It should be noted that these 
methods need to be updated on the basis of full-scale studies in modern facilities, with state-of-the-art animal housing and feeding technologies In Russian conditions.

Column E shows the maximum permissible level of emissions calculated on the basis of Russian regulative standards in force. Currently, the valid regulations (Management Directive for Agro-Industrial Complex, RD-APK 1.10.01.02-10 "Recommended Practice for Engineering Designing of Cattle Farms; RD-APK 1.10.02.04-12 for Pig Farms and Complexes and RD-APK 1.10.05.04-13 for Poultry Farms) set the maximum permissible concentration of ammonia (not emissions) in the livestock house (column G) and minimum ventilation rate (column F) for each category of animals. These data allow calculating the maximum possible emission from the housing system, as the product of the gas concentration value and the ventilation rate value.

The analysis showed that:

- The aggregated values of the maximum possible ammonia emissions from livestock housing according to Russian regulations are close to the enlarged EMEP and TFRN indicators. The biggest difference in the data for pigs: $15.6 \mathrm{~kg} \mathrm{NH}_{3} /$ animal place/year (column E) and $6.45 \mathrm{~kg} \mathrm{NH}_{3} /$ animal place/year (column A) for farrowing sows; $4.68 \mathrm{NH}_{3}$ /animal place/year (column E) and $2.87 \mathrm{NH}_{3}$ /animal place/year (column A) for fattening pigs. This difference can be explained by different estimated weight of animals.

- Emission data for existing Russian enterprises are found in the range of BREF BAT-AELs values; for example, for fattening pigs, the farms in Leningrad Region demonstrate ammonia emissions of $1.9-3 \mathrm{~kg}$ $\mathrm{NH}_{3}$ /animal place/year while BAT-AELs are 0.1-2.6 kg NH $3 /$ animal place/year. This can be explained by the fact that technologies and equipment on modern Russian enterprises mostly comply with current European standards.

- It is of interest to note that EMEP emission factors are higher than those obtained on the operating enterprises in Leningrad Region. This indicates the need to collect the necessary data for the transition to Tier 2 when calculating ammonia emissions using the EMEP methods at the country level.

- BAT-AELs can be used as a guide In Russian BAT reference books. To approve these indicators as a standard and to apply them when issuing the integrated environmental permits, some additional research is needed. It seems very difficult to ensure the reliability and objectivity of these estimates when applied in practice.

BREF and Ammonia Guidance document define the ammonia emission standard for livestock housing only. When manure storage and application technologies are identified as BAT, BREF and Ammonia Guidance document show not the absolute values of the indicators, but the degree of emission reduction in different technologies compared to the reference, although it would be logical to establish the standards also for the emissions from all these technologies. This can be explained by the fact that emission rating from storage facilities and manure application is technically and methodically less grounded. In addition, BREF establishes the limiting values of nitrogen content in animal excrements (for the assessment of feeding system effectiveness) and the recommended time of soil incorporation of manure after its application. To apply these indicators as standards in the environmental assessment at the stage of obtaining integrated environmental permits additional studies are needed.

The above proves that other methods of environmental impact assessment are to be considered.

\section{NITROGEN USE EFFICIENCY FOR ENVIRONMENTAL IMPACT ASSESSMENT}

The criteria and indicators for farm assessment must be easily understood; they have to be comparable, measurable and formalisable. Such requirements are met by the methods, which assess the effectiveness of nutrient use, nitrogen in particular, and determine the potential environmental risk of an agricultural enterprise (Bittman et al., 2014; EU Nitrogen Expert Panel, 2015). Calculations of nutrient balances at farm level are introduced in many European countries (Umweltbundesamt, 2015).

To assess the results of nitrogen transformation, different terminology and dimensions are used depending on the models applied to describe the processes and tasks, with the main ones being "losses" and "NUE - nitrogen use efficiency". If at the input of the system (it can be an animal farm, a separate technology or its element) (Bittman et al., 2014) the amount of nitrogen will be denoted as $N_{\text {input }}$, and at the output the amount of nutrients will be $N_{\text {output }}$, then losses are determined as $N_{\text {losses }}=\sum N_{\text {input }}-\sum N_{\text {output }}, \mathrm{kg} /$ year. Nitrogen use efficiency NUE is usually defined in fractional form as a dimensionless value: $N U E=\frac{\sum N_{\text {output }}}{\sum N_{\text {input }}}$ or as a percentage: $=\frac{\sum N_{\text {output }}}{\sum N_{\text {input }}} 100 \%$.

For an agricultural enterprise $N_{\text {surplus }}=\frac{\sum N_{\text {inputs }}-\sum N_{\text {outputs }}}{\text { area of agricultural land }}, \mathrm{kg} / \mathrm{ha} /$ year is also calculated.

Calculation method of nitrogen balance (Bittman et al., 2014) was tested for agricultural enterprises in Leningrad Region. The nitrogen farm-gate balance considers the nitrogen inputs in purchased feed and fertilisers and nitrogen outputs in sold products. Nitrogen flows inside the farm are not considered. The resulting value of $N_{\text {surplus }}$ at farm level, is the amount of nutrients, which were not used for crops nutrition, and are practically lost. As $N_{\text {surplus }}$ is the sum of nitrogen retained in the soil and nitrogen emitted to the atmosphere and ground water; it can characterise the environmental load and be considered as an environmental indicator. Table 2 shows the fragment of the farm-gate balance calculation for a farm in Leningrad Region. 
Table 2. Fragment of farm-gate balance calculation for the farm with 810 dairy cows, 2600 ha of agricultural land and milk yield of $7000 \mathrm{~kg} /$ year

\begin{tabular}{|c|c|c|c|}
\hline INPUTS & Nitrogen. $t$ & OUTPUTS & Nitrogen, $t$ \\
\hline Purchased: & & Sold & \\
\hline Complete feed & 73.55 & Milk & 26.90 \\
\hline Ammonium saltpeter & 68.00 & Beef live weight & 1.97 \\
\hline NPK fertiliser & 18.00 & Pedigree animals & 0.27 \\
\hline \multirow[t]{2}{*}{ Purchased seeds per year } & 0.14 & Young animals & 0.21 \\
\hline & & Cattle for meat & 1.36 \\
\hline Nitrogen fixation & 13.06 & Manure & 1.54 \\
\hline Nitrogen deposition & 13.06 & Potato & 1.02 \\
\hline Total INPUTS & 159.69 & Total OUTPUTS & 33.57 \\
\hline \multicolumn{2}{|l|}{ Calculation results } & & \\
\hline NUE $=\sum$ Noutput $/ \sum$ Ninput & 0.21 & & \\
\hline $\mathrm{N}$ surplus. kg N/ha/yr & 48.29 & & \\
\hline
\end{tabular}

The value of nitrogen excess $\mathrm{N}_{\text {surplus }}$ for this farm is $48.3 \mathrm{~kg} / \mathrm{ha}$ that is below the limit values in the EU countries ( $200 \mathrm{~kg} / \mathrm{ha}$ ) and indicates the possibility to increase the volume of nitrogen fertiliser application. At the same time, the value of NUE $=0.21$, is significantly below the European average $(0.5-0.6)$.

NUE values and variability can be used for an integrated assessment of the effectiveness of environmental measures implemented at the enterprise, since all the necessary initial data for calculations can be found in the documents of standard statistical reporting of Russian agricultural enterprises.

To take specific environmental measures and to assess them, all flows of nutrients need to be studied. For the considered set of input data for this farm the nitrogen balance was calculated with the use of the Eurostat and OECD Nutrients Budgets Methodology, which considers all nitrogen flows - inside as well as incoming and outgoing. Figure 2 shows estimated nitrogen flows with due account for the inter-farm linkages between livestock and crop sectors. From the livestock sector to the crop sector nitrogen is supplied during manure field application; from the crop sector to the livestock sector nitrogen comes with the feed of own production.

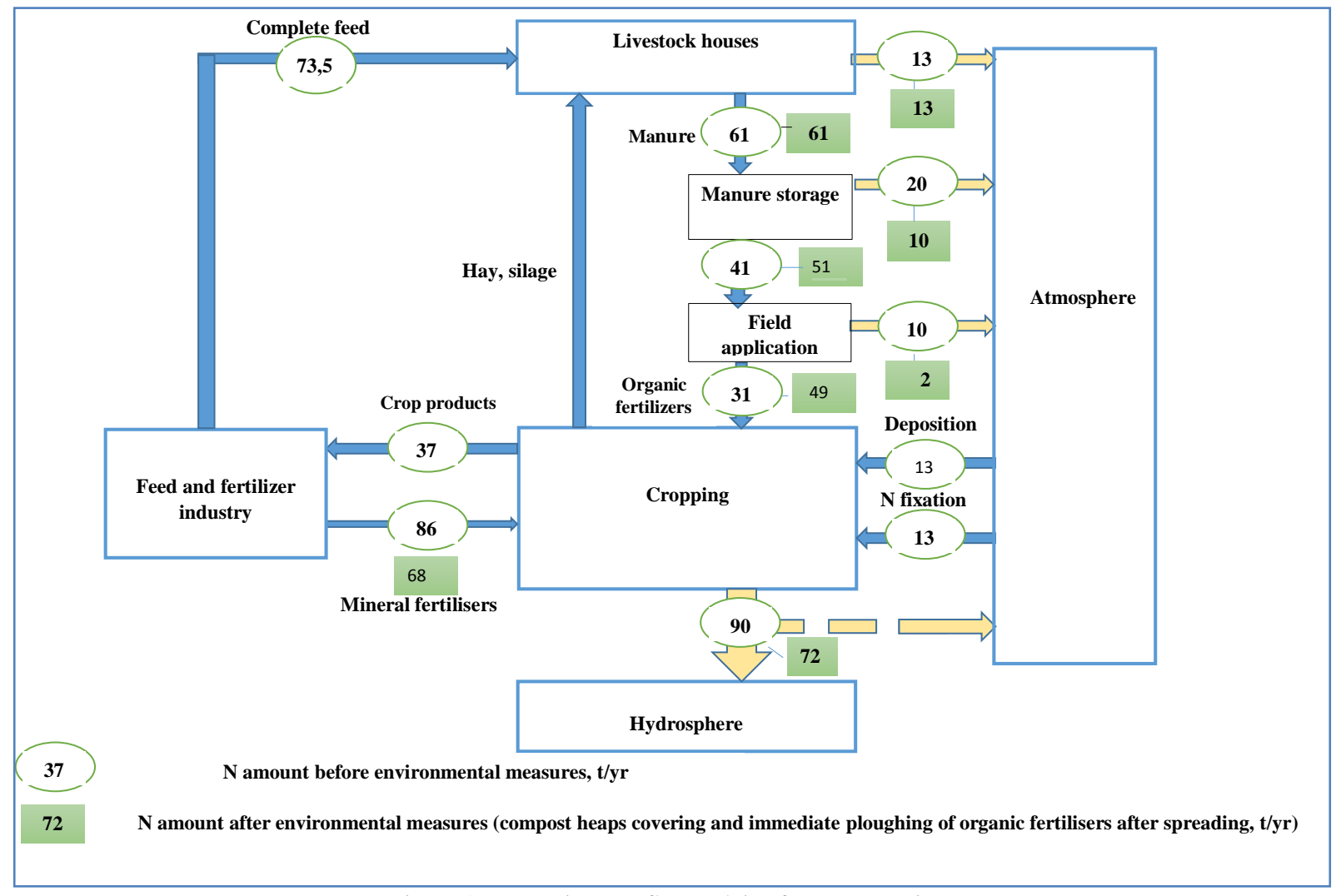

Figure 2. Farm nitrogen flows (dairy farm + cropping)

Figure 2 also demonstrates the assessment results of the effectiveness of the farm introduction of BAT for manure processing and application (covering of compost heaps and immediate ploughing of organic fertilisers after spreading). The numerical values of nitrogen flows are shown before and after BAT introduction. The calculated values of total nitrogen losses are reduced by $20 \%$; the saving of mineral fertilisers owing to higher nitrogen content in applied organic fertilisers can be $18 \mathrm{t} /$ year. 


\section{CONCLUSION}

For the rough assessment of technologies on the initial stage of Russian reference books creation it is practicable to use the BAT-AELs values from EU BREF on intensive rearing of pigs and poultry. Emission data for currently operating Russian enterprises are found to be in the range these values: for fattening pigs the farms in Leningrad Region demonstrate ammonia emissions of 1.9-3 kg NH$/$ animal place/year while BAT-AELs are 0.1-2.6 $\mathrm{kg} \mathrm{NH}_{3} /$ animal place/year; for laying hens (cage system) $-0.03 \mathrm{~kg} \mathrm{NH}_{3} /$ animal place/year while BAT-AELs are $0.02-0.08 \mathrm{~kg} \mathrm{NH}_{3} /$ animal place/year.

When farms are assessed on the stage of integrated permits issue it is feasible to use the measured air concentrations of hazardous substances along with the estimation of the whole-farm environmental impact by nitrogen use efficiency (NUE). NUE is an integrated index of environmental load and meets all requirements to an indicator (it is easy to calculate, convenient to compare, understandable to the farmer and can be verified in case of falsification). For such estimates to be applied in Russia, the data needs to be collected and systematised for different categories of farms and for different climatic regions.

Calculation method of farm-gate balance was tested for the farm with 810 dairy cows, 2600 ha of agricultural land and milk yield of $7000 \mathrm{~kg} / \mathrm{year}$ per cow on the base of the farm statistic reporting. $\mathrm{N}_{\text {surplus }}$ for this farm was found to be $48.3 \mathrm{~kg} / \mathrm{ha}$ that is below the limit values in the EU countries $(200 \mathrm{~kg} / \mathrm{ha})$. The value of NUE $=0.21$, is significantly below the European average ( 0.5 - 0.6) and this require specific improvement measures (BAT for example) to be taken in both livestock and crop farming.

Introduction effectiveness of BAT for manure processing and application for this farm was assessed by considering all $\mathrm{N}$ flows with use of the Eurostat and OECD Nutrients Budgets Methodology. Calculated total nitrogen losses are reduced by $20 \%$; the saving of mineral fertilisers owing to higher nitrogen content in applied organic fertilisers can be 18 t/year.

\section{REFERERNCES}

1. Bittman, S., Dedina, M., Howard C.M., Oenema, O., Sutton, M.A. 2014. Options for Ammonia Mitigation: Guidance from the UNECE Task Force on Reactive Nitrogen, Centre for Ecology and Hydrology, Edinburgh, UK.

2. Briukhanov, A. Yu., Kozlova, N.P., Vasilev, E.V.,Shalavina E.V. 2016.Recommendations how to identify the BATs for intensive livestock farming in IEEP Publishers, Saint Peterburg. Rekomendatsii po opredeleniyu nailuchshikh dostupnykh tekhnologiy dlya intensivnogo zhivotnovodstva. [In Russian]

3. EMEP/EEA emission inventory guidebook 2013 update July 2015. 3.B Manure management. Available at https://www.eea.europa.eu/publications/emep-eea-guidebook-2013/part-b-sectoral-guidance-chapters/4-agriculture/3-bmanure-management (Accessed on 12/11/2017)

4. EU Nitrogen Expert Panel. 2015. Nitrogen Use Efficiency (NUE) - an indicator for the utilization of nitrogen in agriculture and food systems. WageningenUniversity, Alterra, POBox 47, NL-6700 Wageningen, Netherlands. Available at http://www.eunep.com/wp-content/uploads/2017/03/Report-NUE-Indicator-Nitrogen-Expert-Panel-18-12-2015.pdf (Accessed on $12 / 11 / 2017$ )

5. Eurostat. 2013. Nutrients Budgets - Methodology and Handbook. Version 1.02. Eurostat and OECD, Luxembourg. Available at http://ec.europa.eu/eurostat/documents/2393397/2518760/Nutrient_Budgets_Handbook_\%28CPSA_AE_109\%29_corrected3.p df/4a3647de-da73-4d23-b94b-e2b23844dc31 (Accessed on 12/11/2017)

6. Kozlova N.P., Maximov N. V. 2010. Assessment of ammonia and carbon dioxide emission from cattle buildings. Proceedings of the conference "Cnizheniye otritsatel'nogo vozdeystviya na okruzhayushchuyu sredu khimicheski aktivnogo azota pri proizvodstve selskokhozyaystvennoy produktsii”, pp. 114-123 SZNIIMESH, Saint Petersburg. [In Russian]

7. Management Directive for Agro-Industrial Complex (RD-APK) 1.10.01.02-10 Recommended Practice for Engineering Designing of Cattle Farms. 2011. Ministry of Agriculture and Food of the Russian Federation . [In Russian]. Metodicheskiye rekomendatsii po tekhnologicheskomu proyektirovaniyu ferm i kompleksov krupnogo rogatogo skota RD-APK 1.10.01.02-10 Moskva MSKH RF .

8. Management Directive for Agro-Industrial Complex (RD-APK) 1.10.02.04-12 Recommended Practice for Engineering Designing of Pig Farms and Complexes". 2012. Ministry of Agriculture and Food of the Russian Federation. [In Russian]. Metodicheskiye rekomendatsii po tekhnologicheskomu proyektirovaniyu svinovodcheskikh ferm i kompleksov RD-APK 1.10.02.04-12, Moskva. MSKH RF.

9. Management Directive for Agro-Industrial Complex (RD-APK) 10.05.04-13 "Recommended Practice for Engineering Designing of Poultry Farms. 2013,. Ministry of Agriculture and Food of the Russian Federation. [In Russian]. Metodicheskiye rekomendatsii po tekhnologicheskomu proyektirovaniyu ptitsevodcheskikh predpriyatiy RD-APK 1.10.05.04-13 Moskva MSKH RF.

10. Morozova, N.M. Golovina, I.A. Ignatyeva Y.S. 2014. National registration of nitrogen emissions in the Russian Federation. In K.W.Van der Hoek and Kozlova N.P Eds." Ammonia workshop 2012 Saint Petersburg: abating ammonia emissions in the Unece and EECCA region" 141-149.Bilthoven, the Netherland, Available at http://www.rivm.nl/dsresourceobjectid=efbe7cf1-e11b4182-a576-932e51935be7\&type=org\&disposition=inline (Accessed on 12/11/2017)

11. Santonja G., Georgitzikis Konstantinos, Scalet Bianca Maria, Montobbio Paolo, Roudier Serge, Sancho Luis Delgado. 2017.Best Available Techniques (BAT) Reference Document for the Intensive Rearing of Poultry or Pigs; EUR 28674 EN; doi:10.2760/020485

12. Sanz, C., Gates, R.S., Zhang, G., Estellés, F., Ogink, N.W.M., Pedersen, S., Berckmans, D. 2013. Measuring gas emissions from livestock buildings: A review on uncertainty analysis and error sources. Biosystems Engineering. 116:221-231. https://doi.org/10.1016/j.biosystemseng.2012.11.004 
13. SRI Atmosphere. 1999. Methodology for calculating the emissions (emissions) of pollutants into the atmosphere from livestock complexes and fur farms. [In Russian]. Metodika rascheta vydeleniy (vybrosov)zagryaznyayushchikh veshchestv v atmosferu ot zhivotnovodcheskikh kompleksov i zveroferm ( po velichinam udel'nykh pokazateley. NII Atmosfera. Sankt-Peterburg

14. Sutton, M.A., Howard, C.M., Erisman, J.W., Billen, G., Bleeker, A., Grennfelt, P., van Grinsven, H., Grizzetti, B. 2011. The European Nitrogen Assessment, Cambridge University Press. https://doi.org/10.1017/CBO9780511976988

15. Umweltbundesamt. 2015. Status of nutrient bookkeeping in the Baltic Sea countries. 2015. Dessau-Roßlau. Available at http://www.helcom.fi/Lists/Publications/Status\%20of\%20nutrient\%20bookkeeping\%20in\%20the\%20Baltic\%20Sea\%20countr ies.pdf (Accessed on 12/11/2017)

16. VERA..Verification of Environmental Technologies for Agricultural Production. 2011.Test Protocol for Livestock Housing and Management Systems Version 2 / Available at http://www.vera-verification.eu/fileadmin/download/Test programs/Housing.pdf (Accessed on 12/11/2017) 